\title{
Selection Criteria for Drought-resistance Breeding in Turfgrass
}

\author{
Yuguang Zhao', George C.J. Fernandez ${ }^{2}$, Daniel C. Bowman ${ }^{3}$, and Robert S. Nowak ${ }^{4}$ \\ College of Agriculture, University of Nevada, Reno, NV 89557
}

Additional index words. water-use efficiency, water stress, Gompertz model, relative water content, canopy temperature, biplot display

\begin{abstract}
Cumulative evapotranspiration (ET cum $_{\text {) }}$ patterns of 10 commercially available cool-season turfgrass species and cultivars were evaluated under progressive water stress in the semi-field conditions using a gravimetric mass balance method in three studies. At the end of water stress, the cultivars were visually scored for green appearance on a 0 (no green)

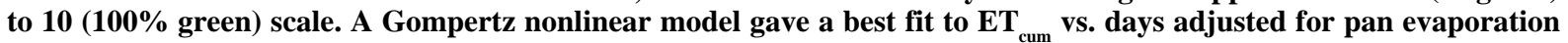

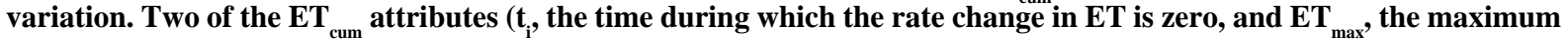
ET rate) estimated from the Gompertz model appeared to reflect efficient water-use attributes in the turfgrass. Among the physiological screening techniques studied, electrolyte leakage, relative water content, and the difference between canopy and air temperature appeared to separate cultivars by drought resistance and water use efficiency (WUE). These physiological attributes were also relatively easy to measure and had high correlations with color score and WUE. Biplot display is a graphical technique in which the interrelationships between the cultivars and water-use attributes can be displayed together. Based on $t_{i}$, ET ${ }_{\text {max }}$, color score, and physiological attributes, 'Wabash' and 'Bristol' Kentucky bluegrass (Poa pratensis L.), 'Aurora' hard fescue (Festuca ovina var.duriuscula L. Koch.), and 'FRT-30149' fine fescue ( $F$. rubra $L$.) were identified as cultivars with higher WUE.
\end{abstract}

Interest in water conservation by the turfgrass industry establishes the need for breeding drought-resistant species and cultivars (Salaiz et al., 1991). The results of many studies on evapotranspiration (ET) rates, between and within turfgrass species under nonlimiting moisture conditions, are summarized by Beard (1985, 1990) and reviewed by Kneebone et al. (1992). These studies only measure the initial phase of the turf water-use curve. Fernandez and Love (1993) suggested that water-use measurements under nonlimiting conditions are not good predictors of low water-use patterns under restricted water use, which may be appropriate to conserve water. These authors found that, under greenhouse conditions, a significant cultivar $\times$ day interaction occurred under progressive water stress, and a nonlinear Gompertz model was used to describe the cumulative ET ( $\mathrm{ET}_{\text {cum }}$ ) pattern for the turfgrasses. Two ET ${ }_{\text {cum }}$ attributes ( $\mathrm{t}_{\mathrm{i}}$, the time during which the rate change in ET is zero, and $\mathrm{ET}_{\max }$, the maximum ET rate) estimated from the Gompertz model were highly correlated with color score. Based on final $\mathrm{ET}_{\text {cum }}\left(\mathrm{FET}_{\text {cum }}\right.$, accumulated ET over the experimental period), $\mathrm{ET}_{\text {max }}^{\text {cum }}, \mathrm{t}_{\mathrm{i}}$, and color score, cultivars with low water use were identified. However, $\mathrm{ET}_{\text {cum }}$ patterns of the cultivars under progressive water stress in the field may differ from those in the greenhouse.

Several physiological techniques have been suggested for drought-resistance screening, including leaf water potential $(\psi)$ (Fisher and Sanchez, 1979; Sojka et al., 1981), relative water content (RWC) (Matin et al., 1989), canopy temperature $\left(\mathrm{T}_{c}\right)$ (Blum et al., 1982; Sullivan and Ross, 1979), and electrolyte leakage (EL) (Levitt, 1980; Sullivan, 1972). These and other potential screening techniques are discussed in several reviews

Received for publication 7 Jan. 1994. Accepted for publication 20 June 1994. Supported by Nevada Agricultural Experiment Station project no. 420. The cost of publishing this paper was defrayed in part by the payment of page charges. Under postal regulations, this paper therefore must be hereby marked advertisement solely to indicate this fact.

${ }^{1}$ Graduate student.

${ }^{2}$ Associate professor in plant breeding and biometrics; to whom reprint requests should be addressed.

${ }^{3}$ Associate professor in biochemistry.

${ }^{4}$ Associate professor in environmental and resource sciences.
(Blum, 1988; Hanson and Nelson, 1980). Hanson and Nelson (1980) examined agronomic, physiological, and biochemical approaches that might be used in a breeding program for assessing cultivar sensitivity to drought. They suggested that an ideal screening test should be 1) highly correlated with drought resistance under field conditions under which drought stress occurred at the growth stage or stages at which the component is expressed;2) rapid, accurate, and able to handle many samples during the season; and 3) nondestructive.

The objectives of this study are to 1) determine the comparative ET rates of turfgrass grown in pots subjected to progressive water stress under semi-field conditions; 2) test for a significant cultivar $\times$ day interaction under progressive water stress; 3) identify cultivars with efficient water-use potentials; 4 ) compare the effectiveness of several physiological screening techniques; and 5) study the interrelationships among $\mathrm{ET}_{\text {cum }}\left(\mathrm{t}_{\mathrm{i}}, \mathrm{ET}_{\max }\right)$ and the physiological screening components.

\section{Materials and Methods}

Experiment I. In February 1991, 10 turfgrass cultivars (Table 1) were selected based on their $\mathrm{ET}_{\text {cum }}$ pattern under greenhouse conditions (Fernandez and Love, 1993) and established in plastic pots. The pots were $30 \mathrm{~cm}$ in diameter $\times 22 \mathrm{~cm}$ high with a separate water reservoir $(26 \mathrm{~cm}$ in diameter $\times 5 \mathrm{~cm} \mathrm{high})$ at the bottom of the container. The pots were filled with Dialoam (Eagle-Pitcher Minerals, Reno, Nev.), chosen for its water-retention properties (Van Bavel et al., 1978). After germination, the turf was established for 6 months. During this period, the turf was irrigated with half-strength Hoagland's solution (Hoagland and Arnon, 1950) and mowed to a height of $5 \mathrm{~cm}$. On 9 Aug. 1991, pots were moved into prepositioned plastic sleeves located within a turfgrass field at the Univ. of Nevada-Reno Valley Road Farm. The sleeves were 31 $\mathrm{cm}$ in diameter and $28 \mathrm{~cm}$ deep and arranged in 5 blocks of 10 units.

On 19 Aug. after the turf had adjusted for 10 days to the field conditions, the pots were watered thoroughly with nutrient solution to fill the reservoir. Pots were not watered until 10 Sept. 1991 to impose progressive water stress. Water loss by the turfgrass was measured daily by the gravimetric mass-balance method (Bow- 
Table 1. Species, cultivars, and their seeding rates and water-use efficiency (WUE) in Expts. I, II, and III.

\begin{tabular}{|c|c|c|c|}
\hline Species & $\begin{array}{l}\text { Seeding } \\
\text { rate } \\
\left(\mathrm{g} \cdot \mathrm{m}^{-2}\right)\end{array}$ & Cultivar & WUE $^{\mathrm{z}}$ \\
\hline \multicolumn{4}{|c|}{ Expt. I } \\
\hline $\begin{array}{r}\text { Kentucky bluegrass } \\
\text { (Poa pratensis L.) }\end{array}$ & $16^{\mathrm{y}}$ & $\begin{array}{c}\text { Abbey } \\
\text { Bristol } \\
\text { Wabash }\end{array}$ & $\begin{array}{c}\text { Unknown } \\
\text { High } \\
\text { High }\end{array}$ \\
\hline $\begin{array}{l}\text { Perennial ryegrass } \\
\text { (Lolium perenne L.) }\end{array}$ & 50 & $\begin{array}{l}\text { Caravelle } \\
\text { Citation } \\
\text { Omega }\end{array}$ & $\begin{array}{c}\text { Unknown } \\
\text { Low } \\
\text { Low }\end{array}$ \\
\hline $\begin{array}{l}\text { Tall fescue } \\
\text { (Festuca arundinacea } \text { Schreb.) }\end{array}$ & 100 & $\begin{array}{l}\text { Apache } \\
\text { Bonanza }\end{array}$ & $\begin{array}{l}\text { Low } \\
\text { Low }\end{array}$ \\
\hline $\begin{array}{l}\text { Sheep fescue } \\
\quad(\text { F. ovina L.) }\end{array}$ & 50 & MX86 & High \\
\hline $\begin{array}{l}\text { Creeping fescue } \\
(F . \text { rubra L. })\end{array}$ & $\begin{array}{l}50 \\
\text { and III }\end{array}$ & Shademaster & High \\
\hline $\begin{array}{l}\text { Kentucky bluegrass } \\
(P . \text { pratensis L.) }\end{array}$ & 8 & $\begin{array}{c}\text { Abbey } \\
\text { Bristol } \\
\text { Challenger } \\
\text { Wabash }\end{array}$ & $\begin{array}{c}\text { Unknown } \\
\text { High } \\
\text { High } \\
\text { High }\end{array}$ \\
\hline $\begin{array}{l}\text { Tall fescue } \\
\text { (F. arundinacea Schreb.) }\end{array}$ & 50 & $\begin{array}{c}\text { Arid } \\
\text { Bonanza }\end{array}$ & $\begin{array}{l}\text { Low } \\
\text { Low }\end{array}$ \\
\hline $\begin{array}{l}\text { Sheep fescue } \\
(\text { F. ovina } \mathrm{L} .)\end{array}$ & 25 & $\begin{array}{l}\text { Meck } \\
\text { MX86 }\end{array}$ & $\begin{array}{l}\text { Unknown } \\
\text { High }\end{array}$ \\
\hline $\begin{array}{l}\text { Fine fescue } \\
(\text { F. rubra L.) }\end{array}$ & 25 & FRT-30149 & High \\
\hline $\begin{array}{l}\text { Hard fescue } \\
\text { (F. ovina var. duriuscula L. Koch.) }\end{array}$ & 25 & Aurora & High \\
\hline
\end{tabular}

${ }^{\mathrm{z}}$ Classified based on a study by Fernandez and Love (1993).

${ }^{y}$ Seeding rates for turfgrasses in Expt. I were doubled to compensate for low germination rates.

man and Macaulay, 1991). On days 0 and 20, the turfgrass cultivars were scored visually for green retention on a 0 to 10 scale, where $9=90 \%$ of the leaf tissue green and $1=90 \%$ of the leaf tissue scorched (Fernandez and Love, 1993). Final color score was adjusted using the initial color score (on day 0) as a covariate to eliminate any preexisting difference among cultivars. Adjusted final color score was estimated from the least square means. Water-use efficiency (WUE) was calculated by dividing the adjusted final color score by $\mathrm{FET}_{\text {cum }}$. The turf was mowed once on day 14 of the dry-down period. Weather conditions during this and subsequent experimental periods are presented in Table 2.

The experimental design for water-stress treatment in Expt. I was a randomized complete-block design with three replications. Well-watered pots (watered at the time of each weighing with half-strength Hoagland's solution to fill the reservoir) were set between the treatments with two replications. Cultivar mean of $\mathrm{ET}_{\text {cum }}$ of the well-watered turf was used to correct day-to-day variation by estimating adjusted days in two steps.

Step I: Daily average ET of well-watered turf = cultivar mean of $\mathrm{FET}_{\text {cum }}$ /total number of days under progressive water stress.
Table 2. Weather conditions during the experiments. ${ }^{\mathrm{z}}$

\begin{tabular}{|c|c|c|c|c|c|}
\hline \multicolumn{2}{|c|}{ Temp $\left({ }^{\circ} \mathrm{C}\right)$} & \multirow{2}{*}{$\begin{array}{c}\text { Solar } \\
\text { radiation } \\
(\mathrm{Ly})\end{array}$} & \multirow{2}{*}{$\begin{array}{c}\text { Wind } \\
\text { speed } \\
(\text { miles } / \mathrm{h})\end{array}$} & \multirow{2}{*}{$\begin{array}{c}\text { Relative } \\
\text { humidity } \\
(\%)\end{array}$} & \multirow{2}{*}{$\begin{array}{c}\text { Pan } \\
\text { evapotranspiration } \\
\left(\mathrm{mm} \cdot \mathrm{day}^{-1}\right)\end{array}$} \\
\hline Min & $\operatorname{Max}$ & & & & \\
\hline \multicolumn{6}{|c|}{ Expt. I (19 Aug. to 10 Sept. 1991) } \\
\hline \multicolumn{6}{|c|}{ Expt. II (10 to 25 July 1992) } \\
\hline 10.9 & \multicolumn{4}{|c|}{ Expt. III (1 to 17 Sept. 1992) } & 8.33 \\
\hline 5.6 & 28.6 & 402.73 & 1.60 & 33.8 & 6.51 \\
\hline
\end{tabular}

${ }^{\mathrm{z}}$ Mean value over the experiments.

Step II: Adjusted days = cultivar mean of $\mathrm{ET}_{\text {cum }}$ at $\mathrm{i}^{\text {th }}$ day/daily average ET.

Experiment II. In March 1992, the experiment was repeated with 10 turfgrass cultivars (Table 1). Perennial ryegrass cultivars used in Expt. I were not included because of their high water-use rates and poor color scores. The pots and growth medium were the same except that the reservoir at the bottom of the pot was not used for water storage; also, four drainage holes were bored at the bottom of each reservoir to prevent flooding. After germination, the turf was established in the greenhouse for 4 months. On 25 June 1992 , the pots were moved into the prepositioned sleeves located in the turfgrass field. The sleeves were the same as in Expt. I, except the bottom of the sleeves was constructed with a $10-\mathrm{cm}$ layer of gravel to facilitate drainage. The sleeves were arranged in 5 rows of 10 units each, west to east. On 10 July 1992, pots were watered thoroughly with half-strength Hoagland's solution until run-through. The pots were not watered until 25 July 1992. Pots were weighed on days $0,2,4,7,10,12$, and 14 . On days 0 and 14, the turfgrass cultivars were scored for green retention, and adjusted color score and WUE were estimated as in Expt. I.

The experimental design for water-stress treatment in Expt. II was a randomized complete-block design with four replications. Well-watered turf pots were set in between treatments with one replication. Pots were rotated every 2 days within each block to warrant good randomization. ET $_{\text {cum }}$ of the well-watered turf pots was used to calculate adjusted days as in Expt. I.

Experiment III. Experiment II was repeated, using the same cultivars, the same experimental design with three replications, and under the same field conditions. Thirty-seven days were allowed between the two experiments to let the stressed turfgrass cultivars recover from water stress. During the recovery period, the pots were irrigated using half strength Hoagland's solution every 2 days. At the start of Expt. III, color scores had reached at least 7.

Progressive water stress was imposed on these cultivars by withholding water for 16 days, starting 1 Sept. Turfgrass ET was measured on days $0,2,4,6,8,10,12,14$, and 16 thereafter. On days 0 and 16, the turfgrasses were scored visually as before and an adjusted final green color score and WUE were calculated.

Physiological measurements on WUE. In Expts. II and III, the following physiological screening techniques were used and evaluated: 1) $\psi$; 2) RWC; 3) $\mathrm{T}_{c}$ and $\Delta \mathrm{T}$; and 4) EL.

The $\psi$ was measured by a thermocouple psychrometer (series 74; J.R.D. Merrill Specialty Equipment, Logan, Utah) and a nanovoltmeter (model NT-3; Decagon Devices, Pullman, Wash.). About $0.5 \mathrm{~g}$ of progressively stressed ( 2 days before the end of the stress treatment) turfgrass leaves were excised between 8 and 10 AM, put into the psychrometer chamber, and immediately sealed with the thermocouple assembly. The assembly was allowed to 
equilibrate in a water bath at $25 \mathrm{C}$ for $4 \mathrm{~h}$. Psychrometer measurements were taken by first measuring the zero offset, cooling for 30 sec, then measuring the peak voltage. The $\psi$ was calculated with a computer program (Brown and Bartos, 1982). All psychrometer were individually calibrated with standard $\mathrm{NaCl}$ solutions.

RWC was determined gravimetrically. About $0.6 \mathrm{~g}$ progressively stressed ( 3 days before the end of the stress treatment) leaves was excised between 8 and $10 \mathrm{Am}$, put into scintillation vials, sealed immediately, and transported to the lab. Fresh weight was measured and the leaves were then floated on distilled water under continuous fluorescent light (photosynthetic photon flux density was $100 \pm 15 \mu \mathrm{mol} \cdot \mathrm{m}^{-2} \cdot \mathrm{s}^{-1}$ ) for $24 \mathrm{~h}$ at room temperature. Leaves were then blotted dry and turgid weight was determined. Next the leaves were dried at $70 \mathrm{C}$ for $48 \mathrm{~h}$ and dry weight was taken. RWC was calculated according to equation (Barrs, 1968): RWC (\%) $=100$ (fresh weight - dry weight)/(turgid weight - dry weight)

$\mathrm{T}_{\mathrm{c}}$ was determined with a hand-held infrared thermometer (Telatemp Corp., Fullerton, Calif.) between 11 AM and 2 PM on progressively stressed turf (3 days before the end of the stress treatment). The thermometer was held $1 \mathrm{~m}$ above the turf at a 45 -degree angle from horizontal. $\Delta \mathrm{T}$ was determined at the same time.

EL was determined by the procedure of Sullivan (1972). About $0.3 \mathrm{~g}$ of progressively stressed (4 days before the end of the stress treatment) turfgrass leaf segments was cut and placed in scintillation vials between 3 and $5 \mathrm{PM}$, washed with distilled water three times, and drained. Then, $15 \mathrm{ml}$ of distilled water was added to the vials, followed by vacuum infiltration for $15 \mathrm{~min}$. After $24 \mathrm{~h}$ of incubation on a shaker, the first electrical conductivity reading was measured with a conductance meter (model 32; Yellow Springs Instrument Co., Yellow Springs, Ohio) after vigorously mixing the vial contents. Upon completion of the first measurement, the samples were autoclaved for $15 \mathrm{~min}$ to disrupt the cell membrane, then incubated on a shaker for $24 \mathrm{~h}$. Then the second electrical conductivity reading was taken. EL was calculated as $\operatorname{EL}(\%)=100$ $\times$ first reading/second reading.

Statistical analyses. A repeated-measure analysis (Fernandez, 1991) with profile contrast was performed on the ET cum $_{\text {at }}$ adjusted days for all three experiments. For each cultivar, the ET cum mean $^{\text {cum }}$ was fitted with a Gompertz sigmoidal-nonlinear model. The Gompertz model gave the best fit to the $\mathrm{ET}_{\text {cum }}$ patterns based on smaller MSE compared with logistic and monomolecular nonlinear models (data not shown).

\section{Gompertz model: $\mathrm{Y}=\mathrm{a} \exp [-\mathrm{b} \exp (-\mathrm{kt})]$}

where, $\mathrm{Y}=$ predicted $_{\mathrm{ET}}$ cum $; \mathrm{t}=\operatorname{adjusted}$ days $\left(\mathrm{ET}_{\text {cum }}\right.$ at $\mathrm{i}^{\text {th }}$ day $/$ mean $\mathrm{ET}) ; \mathrm{a}=$ the asymptote, theoretical maximum value for $\mathrm{Y} ; \mathrm{b}$ and $\mathrm{k}$ $=$ model parameters with different values for different cultivars.

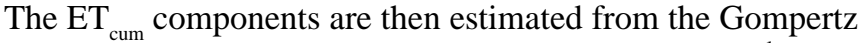
model parameters, $a, b$, and $k$. The ET rate is $k Y \log _{e}\left(a Y^{-1}\right)$. The $\mathrm{ET}_{\max }$ in the Gompertz model occurs when the rate of change in ET
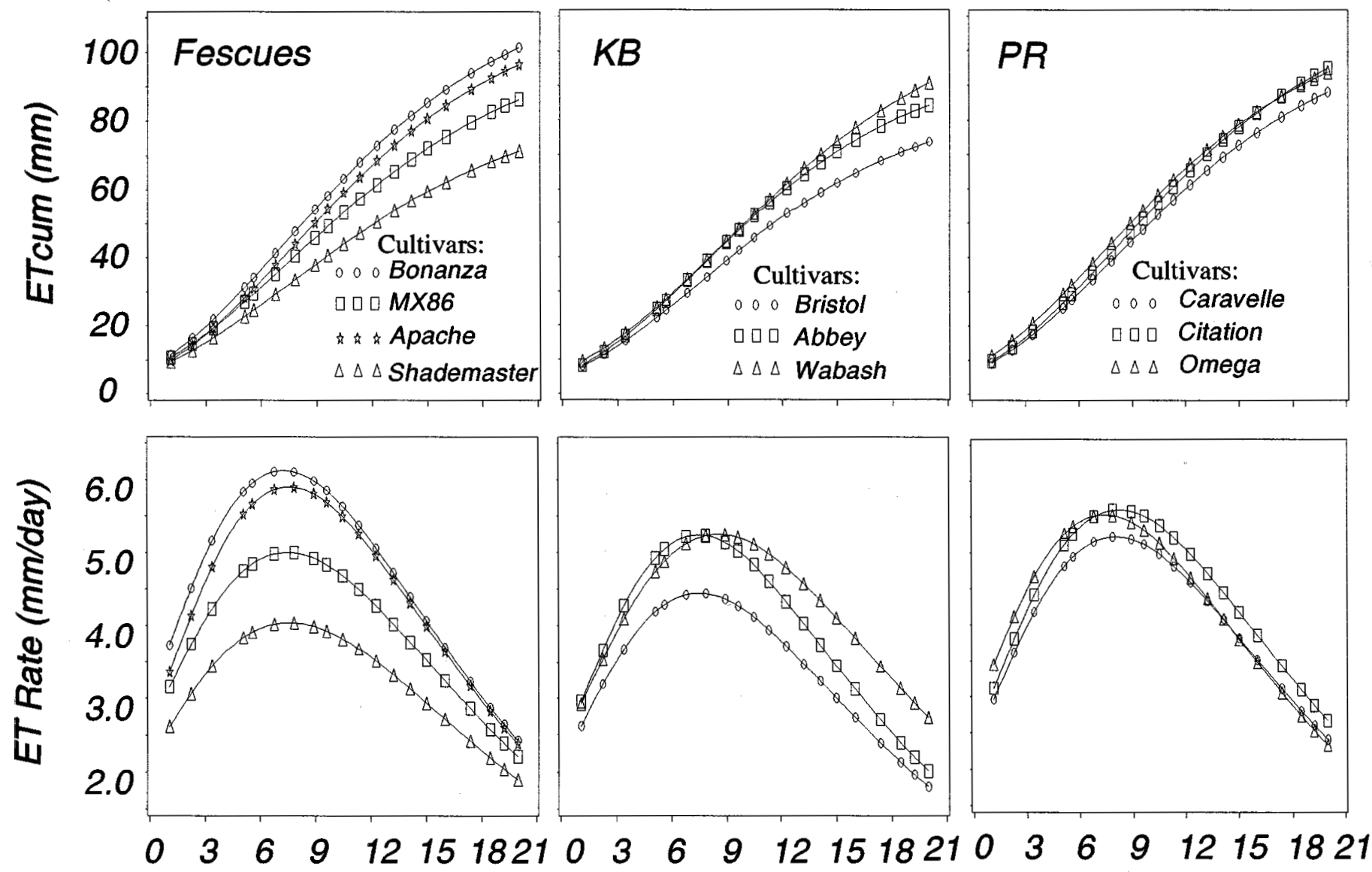

\section{Adjusted days ( $t$ )}

Fig. 1. Gompertz nonlinear model curves for cumulative evapotranspiration $\left(\mathrm{ET}_{\text {cum }}\right)$ and ET rate vs. adjusted days for turfgrass cultivars evaluated under field Expt. I. $\mathrm{KB}=$ Kentucky bluegrass; $\mathrm{PR}=$ perennial ryegrass. The cubic spline option was used to connect the points in these plots. 
is zero at the time of inflection $\left(\mathrm{t}_{\mathrm{i}}\right)$ of the curve: $\mathrm{ET}_{\max }=(k a) e^{-1}$ and $\mathrm{t}_{\mathrm{i}}=\left(\log _{e} b\right) k^{-1}$ (Fernandez and Love, 1993; Tipton, 1984).

From the Gompertz model, $\mathrm{t}_{\mathrm{i}}$ and $\mathrm{ET}_{\text {max }}$ were calculated. For Expt. I, group contrast was performed for color score and FET cum $_{\text {. }}$. In the absence of a significant cultivar $\times$ experiment interaction (verified by Tukey's test for nonadditivity, Tukey, 1949), combined analysis of variance and group contrast comparisons (cultivar means over Expts. II and III) were performed for $t_{i}$, ET ${ }_{\max }$, FET $_{\text {cum }}$, color score, and WUE and all physiological attributes using cultivar $\times$ experiment as the error term for Expts. II and III. The correlations between $\mathrm{FET}_{\text {cum }}, \mathrm{t}_{\mathrm{i}}$, and $\mathrm{ET}_{\max }$ with color score and WUE were determined. The correlations of $t_{i}, \mathrm{ET}_{\max }$, and color score between experiments of this study and a previous greenhouse study (Fernandez and Love, 1993) were also determined using the eight turf cultivars common to both studies.

Biplot display of principal component analysis (Gabriel, 1971) was used to identify cultivars with high WUE. A two-dimensional approximation to a two-way table (rows $\times$ columns) can be obtained from the first two principal components. The biplot shows the cultivars (row points) and WUE-related attributes (including $\mathrm{t}_{\mathrm{i}}, \mathrm{ET}_{\max }, \mathrm{RWC}, \Delta \mathrm{T}, \mathrm{EL}$, and color score, vector coordinates) in a single plot by projecting them onto the plane (thus biplot) in the transformed variable space that accounts for the most variance. Thus, biplot display allows visual appraisal of the structure of a large two-way data matrix, and provides a graphical representation of interaction perns that allows the responses of each cultivar in each WUE-related attribute predicted by the principal component model to be directly identified. The relative angles and the directions between the variable vectors illustrate the strength and negative or positive correlations between variables. The ranking of cultivars based on a given attribute is achieved by ordering the projected points. The PC-SAS (1988) procedures PRINQUAL, FACTOR and GPLOT were used in developing the SAS codes to display the biplot.

\section{Results and Discussion}

Cumulative Evap Transpiration(CET) attributes. Cultivar effects were statistically significant in Expts. I and II $(P=0.01$ and 0.02 , respectively) but not in Expt. III $(P=0.19)$. In repeated-measure analysis, day effects were significant in Expts. I, II, and III $(P=0.0001)$. The cultivar $\times$ day interaction was significant at $\alpha=0.05$ by the $G-G$ adjusted univariate test. Profile contrasts (differences between two adjacent time periods) were used to investigate the cultivar $\times$ day interaction pattern. The results of profile contrasts showed that the cultivar $\times$ day interactions existed prominently between days 2 and 4, 9 and 12, and 16 and 19 in Expt. I (Fig. 1). In Expt. II, the interactions existed prominently between days 10 and 14 (Fig. 2). In Expt. III, the interactions existed between days 4 and 6 and 10 and 12 (Fig. 3).

Cultivar effects for color score and FET ${ }_{\text {cum }}$ were significant $(P$ $=0.04$ and 0.01, respectively) for Expt. I. Cultivar effects were
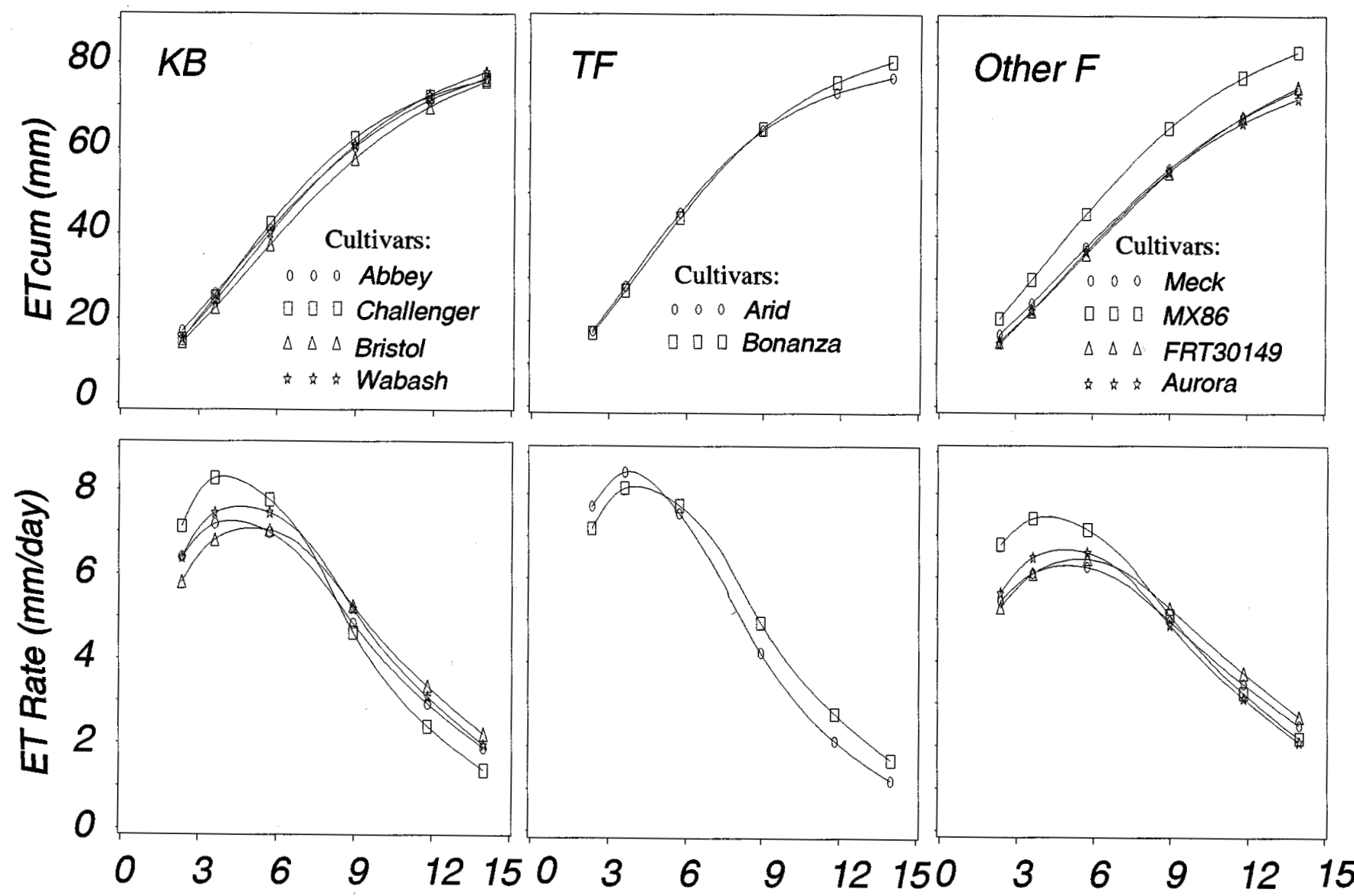

Adjusted days ( $t$ )

Fig. 2. Gompertz nonlinear model curves for cumulative evapotranspiration $\left(\mathrm{ET}_{\mathrm{cum}}\right)$ and ET rate vs. adjusted days for turfgrass cultivars evaluated under field Expt. II. $\mathrm{KB}=$ Kentucky bluegrass; $\mathrm{TF}=$ Tall fescues; Other $\mathrm{F}=$ other fescues. The cubic spline option was used to connect the points in these plots. 
significant for color score $(P=0.0001)$ and WUE $(P=0.0001)$ but not significant for $\mathrm{FET}_{\text {cum }}(P=0.48)$ in the combined analysis of Expts. II and III. Group contrasts for Expt. I and for the combined analysis of Expts. II and III are presented in Tables 3 and 4. Color score and WUE can be used to differentiate an efficient from an inefficient water-use group between and within the same species (Tables 3 and 4). However, FET ${ }_{\text {cum }}$ could not distinguish cultivars within the same species. Group contrasts for $\mathrm{t}_{\mathrm{i}}$ and $\mathrm{ET}_{\max }$ were not performed for Expt. I due to lack of replications. Group contrasts in the combined analysis of Expts. II and III (Table 5) showed that $\mathrm{t}_{\mathrm{i}}$ and $\mathrm{ET}_{\max }$ could differentiate an efficient water-use group from an inefficient water-use group but failed to distinguish cultivars within the same species.

The relationship between $\mathrm{ET}_{\text {cum }}$, ET rate, and adjusted day is shown in Figs. 1-3. Tall fescue and perennial ryegrass had higher ET rate and ET throughout Expt. I (Fig. 1). In Expts. II and III, tall fescue had higher ET rate during the initial phase of the experiments, followed by lower ET in the later phase. As a result, tall fescue had a FET ${ }_{\text {cum }}$ similar to that of Kentucky bluegrass and the fine-leafed fescues (Figs. 2 and 3).

The mean $\mathrm{t}_{\mathrm{i}}, \mathrm{ET}_{\max }, \mathrm{FET}_{\text {cum }}$, color score, and WUE for Expt. 1 and the combined analysis of Expts. II and III are presented in Tables 3 and 4. Longer $t_{\text {i }}$, lower ET max $_{\text {and }}$ ant ${ }_{\text {cum }}$, and higher color scores are desirable attributes that can be used to identify efficient water-use turfgrass cultivars (Fernandez and Love, 1993).

In general, tall fescue ('Arid', 'Apache', and 'Bonanza') had shortert $_{\mathrm{i}}$ (7.2 to 7.6 days in Expt. I equal to 43.5 to $45.9 \mathrm{~mm} \mathrm{in} \mathrm{ET}_{\text {cum }}$ of well-watered turf; 4.0 to 4.3 days in Expts. II and III equal to 27.1

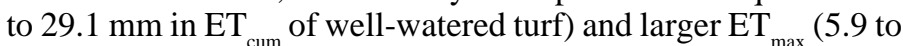
$6.1 \mathrm{~mm} \cdot$ day $^{-1}$ in Expt. I; 7.7 to $8.0 \mathrm{~mm} \cdot$ day $^{-1}$ in Expts. II and III). Even though tall fescue had similar FET ${ }_{\text {cum }}$ to Kentucky bluegrass and the fine-leafed fescues in Expts. II and III (Figs. 2 and 3), they had poor color scores, perhaps due to severe dehydration in the later phase of the experiments. Therefore, they are classified in a lower WUE category.

Perennial ryegrasses had a longer $t_{i}$ ( 7.4 to 8.2 days equal to 44.7 to $49.5 \mathrm{~mm}$ in $\mathrm{ET}_{\text {cum }}$ of well-watered turf) and medium $\mathrm{ET}_{\text {max }}$ (5.2 to $5.6 \mathrm{~mm} \cdot \mathrm{day}^{-1}$ ) but a large $\mathrm{FET}_{\text {cum }}$, probably due to a slower adjustment to the stressful environment. As a result, they had poor color scores and WUEs. Therefore, they are assigned to a low ('Citation' and 'Omega') or medium WUE (cultivar 'Caravelle') category.

'Bristol' and 'Wabash' Kentucky bluegrass, 'FRT-30149' fine fescue, 'Shademaster' creeping fescue, and 'Aurora' hard fescue expressed the more efficient water-use attributes of lower ET (4.4 to $5.3 \mathrm{~mm} \cdot$ day $^{-1}$ in Expts. I; 6.4 to $7.1 \mathrm{~mm} \cdot$ day $^{-1}$ in Expts. II and III), delayed t $\mathrm{t}_{\mathrm{i}}(7.5$ to 8.5 days in Expt. I equal to 45.4 to $51.5 \mathrm{~mm}$ in $\mathrm{ET}_{\text {cum }}$ of well-watered turf; 4.8 to 5.3 days in Expts. II and III equal to 32.4 to $35.4 \mathrm{~mm}_{\text {in }} \mathrm{ET}_{\text {cum }}$ of well-watered turf) and higher color scores and WUE. They are therefore assigned to a higher WUE category.

'Challenger' was identified as a water-use efficient cultivar in a greenhouse study (Fernandez and Love, 1993). However, it was not as efficient as 'Abbey', 'Bristol', and 'Wabash' in Expts. II and
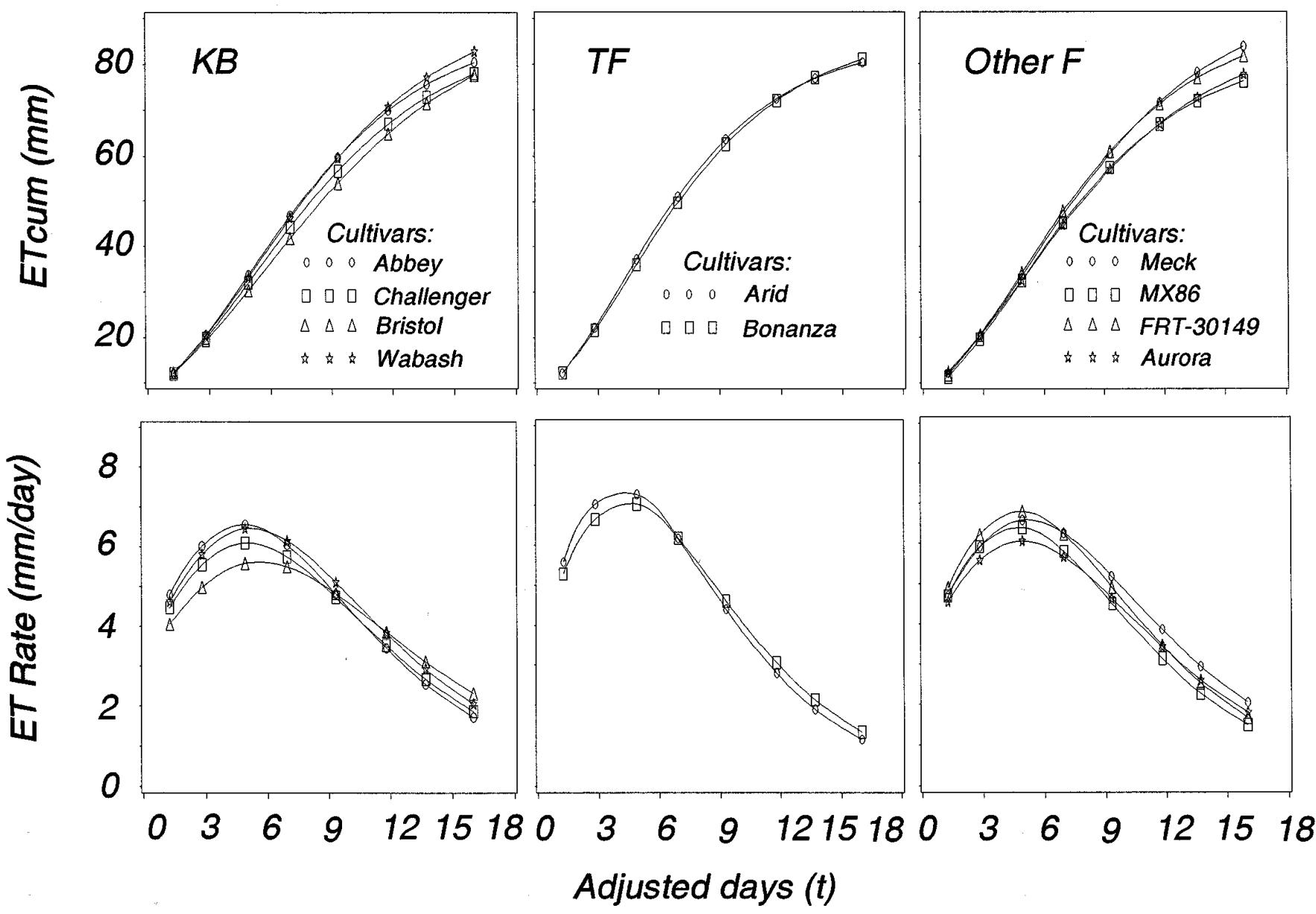

Fig. 3. Gompertz nonlinear model curves for cumulative evapotranspiration $\left(\mathrm{ET}_{\mathrm{cum}}\right)$ and ET rate vs. adjusted days for turfgrass cultivars evaluated under field Expt. III. $\mathrm{KB}=$ Kentucky bluegrass; $\mathrm{TF}=$ Tall fescues; Other $\mathrm{F}=$ other fescues. The cubic spline option was used to connect the points in these plots. 
Table 3. Mean inflection time $\left(\mathrm{t}_{\mathrm{i}}\right)$, maximum evapotranspiration $\left(\mathrm{ET}_{\mathrm{max}}\right)$ estimated from the Gompertz model ${ }^{\mathrm{z}}$, final cumulative ET (FET ${ }_{\text {max }}$ ), adjusted color score, and water-use efficiency (WUE) under progressive water stress in Expt. I.

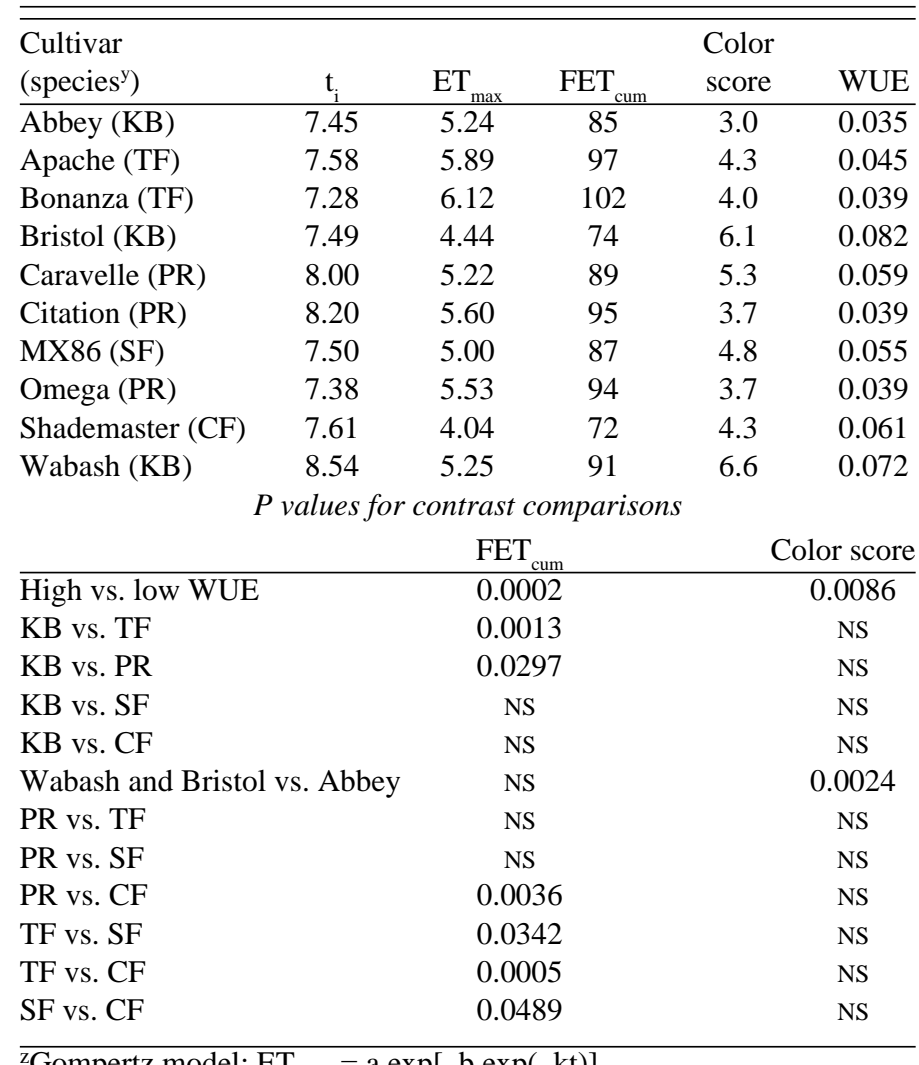

${ }^{\mathrm{z} G o m p e r t z ~ m o d e l: ~} \mathrm{ET}_{\text {cum }}=\mathrm{a} \exp [-\mathrm{b} \exp (-\mathrm{kt})]$.

${ }^{\mathrm{y}} \mathrm{KB}=$ Kentucky bluegrass, $\mathrm{TF}=$ tall fescue, $\mathrm{SF}=$ sheep fescue, $\mathrm{CF}=$ creeping fescue, $\mathrm{PR}=$ perennial ryegrass.

${ }^{\mathrm{x}}$ Classified based on a study by Fernandez and Love (1993) (see Table 1).

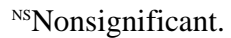

III of this study. 'Abbey' was water-use efficient in the combined analysis but not in Expt. I, probably due to the cultural conditions in Expt. I. In Expt. I, the pots were sealed and potentially anaerobic, which may have been harmful to 'Abbey'. 'Meck' and 'MX86' sheep fescue were significantly different from Kentucky bluegrass, fine fescue, hard fescue, and creeping fescue. Based on these results, 'Challenger', 'Abbey', 'Meck', and 'MX86' were placed in the medium WUE category.

The correlations between $\mathrm{FET}_{\text {cum }}, \mathrm{t}_{\mathrm{i}}$, and $\mathrm{ET}_{\max }$ with color score and WUE for 10 cultivars are shown in Table 5. FET ${ }_{\text {cum }}$ and ET max $_{\text {max }}$ negatively correlated with color score and WUE, whereas $t_{i}$ positively correlated with color score and WUE. None of the correlations were statistically significant except $\mathrm{ET}_{\text {max }}$ with WUE $(P=$ $0.04)$ in Expt. I. However, $\mathrm{ET}_{\max }$ and $\mathrm{t}_{\mathrm{i}}$ significantly correlated with color score and WUE, while FET $\mathrm{F}_{c u m}$ did not correlate significantly in Expts. II and III. It appears that WUE is a superior parameter to color score in that WUE increased the sensitivity of the group contrast test (smaller $P$ values, Table 5) over color score.

The rank correlations of $\mathrm{t}_{\mathrm{i}}, \mathrm{ET}_{\max }$, and color score between field studies and a previous greenhouse study(Fernandez and Love, 1993) were estimated. In general, $\mathrm{ET}_{\max }$ and color score significantly correlated $(r>0.65)$ between the two studies, while $\mathrm{t}_{\mathrm{i}}$ was marginally insignificant.

Under water-limiting conditions, turfgrass appearance is complicated by many factors. First, it is possible that cultivars with high water-use rates could maintain a high color score due to high drought
Table 4. Mean inflection time $\left(\mathrm{t}_{\mathrm{i}}\right)$, maximum evapotranspiration $\left(\mathrm{ET}_{\mathrm{max}}\right)$ estimated from the Gompertz model, final cumulative ET (FET ${ }_{\text {cum }}$ ), adjusted color score, and water-use efficiency (WUE) under progressive water stress in Expts. II and III.

\begin{tabular}{|c|c|c|c|c|c|}
\hline $\begin{array}{l}\text { Cultivar } \\
\left(\text { species }^{\mathrm{z}}\right)\end{array}$ & $\mathrm{t}_{\mathrm{i}}$ & $\mathrm{ET}_{\max }$ & FET $_{\text {cum }}$ & $\begin{array}{l}\text { Color } \\
\text { score }\end{array}$ & WUE \\
\hline$\overline{\text { Abbey (KB) }}$ & 4.59 & 6.93 & 78 & 6.6 & 0.084 \\
\hline Arid (TF) & 3.96 & 7.97 & 78 & 2.4 & 0.031 \\
\hline Aurora $(\mathrm{HF})$ & 4.83 & 6.38 & 75 & 6.2 & 0.083 \\
\hline Bonanza (TF) & 4.29 & 7.66 & 81 & 2.3 & 0.028 \\
\hline Bristol (KB) & 5.27 & 6.38 & 77 & 7.1 & 0.092 \\
\hline Challenger (KB) & 4.60 & 7.25 & 76 & 4.3 & 0.056 \\
\hline FRT-30149 (FF) & 5.03 & 6.63 & 78 & 6.3 & 0.081 \\
\hline Meck (SF) & 5.03 & 6.44 & 80 & 4.4 & 0.056 \\
\hline MX86 (SF) & 4.44 & 6.94 & 80 & 4.3 & 0.054 \\
\hline Wabash (KB) & 4.90 & 7.07 & 80 & 5.8 & 0.073 \\
\hline \multicolumn{6}{|c|}{$P$ values for contrast comparisons ${ }^{y}$} \\
\hline High vs. low WUE ${ }^{x}$ & 0.0011 & 0.0103 & NS & 0.0001 & 0.0001 \\
\hline $\mathrm{KB}$ vs. TF & 0.0017 & 0.0262 & NS & 0.0001 & 0.0001 \\
\hline KB vs. HF & NS & NS & NS & NS & NS \\
\hline KB vs. SF & NS & NS & NS & 0.0029 & 0.0015 \\
\hline KB vs. FF & NS & NS & NS & NS & NS \\
\hline \multicolumn{6}{|l|}{$\begin{array}{l}\text { Wabash, Bristol, and } \\
\text { Abbey vs. }\end{array}$} \\
\hline Challenger & NS & NS & NS & 0.0019 & 0.0018 \\
\hline SF vs. TF & 0.0099 & 0.0191 & NS & 0.0014 & 0.0011 \\
\hline SF vs. FF & NS & NS & NS & 0.0062 & 0.0036 \\
\hline SF vs. HF & NS & NS & NS & 0.0082 & 0.0024 \\
\hline TF vs. FF & 0.0033 & 0.0360 & NS & 0.0001 & 0.0001 \\
\hline TF vs. HF & 0.0130 & 0.0157 & NS & 0.0001 & 0.0001 \\
\hline FF vs. HF & NS & NS & NS & NS & NS \\
\hline
\end{tabular}

${ }_{\mathrm{z}} \mathrm{KB}=$ Kentucky bluegrass, $\mathrm{TF}=$ tall fescue, $\mathrm{SF}=$ sheep fescue, $\mathrm{FF}=$ fine fescue, $\mathrm{HF}=$ hard fescue.

yIn absence of a significant cultivar $\times$ experiment interaction, a combined contrast comparison (genotypic means over Expts. II and III) was performed using cultivar $\times$ experiment as the error term. The significance of cultivar $\times$ experiment was determined by Tukey's test for nonadditivity. ${ }^{x}$ Classified based on a study by Fernandez and Love (1993) (see Table 1).

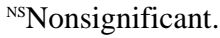

Table 5. Pearson correlation coefficient $(r)$ of mean inflection time $\left(\mathrm{t}_{\mathrm{i}}\right)$, maximum evapotranspiration $\left(\mathrm{ET}_{\max }\right)$, and final cumulative $\mathrm{ET}$ $\left(\mathrm{FET}_{\text {cum }}\right)$ with color score and water-use efficiency (WUE).

\begin{tabular}{|c|c|c|c|c|c|}
\hline \multirow[b]{2}{*}{ Expt. } & \multirow[b]{2}{*}{ Variable } & \multicolumn{2}{|c|}{ Color score } & \multicolumn{2}{|c|}{ WUE } \\
\hline & & $r$ & $P$ & $r$ & $\bar{P}$ \\
\hline \multirow[t]{3}{*}{$\overline{\mathrm{I}}$} & $t_{i}$ & 0.51 & NS & 0.34 & $\overline{\mathrm{NS}}$ \\
\hline & $\mathrm{ET}_{\max }$ & -0.35 & NS & -0.66 & 0.04 \\
\hline & FET $_{\text {cum }}$ & -0.27 & NS & --- & --- \\
\hline \multirow[t]{3}{*}{ II } & $\mathrm{t}_{\mathrm{i}}$ & 0.71 & 0.02 & 0.74 & 0.01 \\
\hline & $\mathrm{ET}_{\max }$ & -0.74 & 0.02 & -0.76 & 0.01 \\
\hline & $\mathrm{FET}_{\text {cum }}$ & -0.28 & NS & --- & --- \\
\hline \multirow[t]{3}{*}{ III } & $\mathrm{t}_{\mathrm{i}}$ & 0.73 & 0.02 & 0.72 & 0.02 \\
\hline & $\mathrm{ET}_{\max }^{1}$ & -0.72 & 0.02 & -0.75 & 0.01 \\
\hline & $\mathrm{FET}_{\text {cum }}$ & -0.08 & NS & --- & --- \\
\hline
\end{tabular}

NsNonsignificant.

tolerance. However, cultivars with high water-use rate are not the goal for breeding water-conserving plants (Beard, 1990). Secondly, in the present study, the roots were grown in a confined space. Caution should be taken when interpreting these results because the plants' ability to extract water from deep layers of soil was excluded. 
Table 6. Mean electrolyte leakage (EL), relative water content (RWC), leaf water potential $(\psi)$, canopy temperature $\left(\mathrm{T}_{\mathrm{c}}\right)$, and canopy-air temperature difference $(\Delta \mathrm{T})$ for combined analysis of Expts. II and III

\begin{tabular}{|c|c|c|c|c|c|}
\hline $\begin{array}{l}\text { Cultivar } \\
\left(\text { species }^{z}\right)\end{array}$ & $\begin{array}{l}\text { EL } \\
(\%)\end{array}$ & $\begin{array}{c}\mathrm{RWC} \\
(\%)\end{array}$ & $\begin{array}{c}\psi \\
(\mathrm{MPa})\end{array}$ & $\begin{array}{c}\mathrm{T}_{\mathrm{c}} \\
\left({ }^{\circ} \mathrm{C}\right)\end{array}$ & $\begin{array}{c}\Delta \mathrm{T} \\
\left({ }^{\circ} \mathrm{C}\right)\end{array}$ \\
\hline Abbey (KB) & 6.4 & 52.9 & -4.46 & 40.0 & 7.4 \\
\hline Arid (TF) & 59.8 & 15.7 & -2.33 & 43.7 & 12.2 \\
\hline Aurora (HF) & 12.6 & 52.5 & -4.04 & 40.2 & 7.7 \\
\hline Bonanza (TF) & 53.0 & 14.8 & -2.93 & 45.9 & 14.2 \\
\hline Bristol (KB) & 10.5 & 62.7 & -2.89 & 39.0 & 6.8 \\
\hline Challenger (KB) & 47.8 & 16.5 & -1.88 & 44.6 & 12.5 \\
\hline FRT-300149 (FF) & 11.3 & 44.3 & -2.37 & 37.0 & 4.9 \\
\hline Meck (SF) & 23.2 & 50.6 & -4.69 & 40.2 & 7.9 \\
\hline MX86 (SF) & 18.6 & 47.9 & -2.29 & 39.4 & 7.2 \\
\hline Wabash (KB) & 6.2 & 47.5 & -1.51 & 40.8 & 8.6 \\
\hline \multicolumn{6}{|c|}{$P$ values for contrast comparisons } \\
\hline \multicolumn{6}{|l|}{ High vs. low } \\
\hline WUE $^{y}$ & 0.0001 & 0.004 & $--{ }^{x}$ & 0.0008 & 0.006 \\
\hline KB vs. TF & 0.0001 & 0.005 & --- & 0.03 & 0.02 \\
\hline KB vs. HF & NS & NS & --- & NS & NS \\
\hline KB vs. SF & NS & NS & --- & NS & NS \\
\hline KB vs. FF & NS & NS & --- & NS & NS \\
\hline \multicolumn{6}{|l|}{$\begin{array}{l}\text { Wabash, Bristol, } \\
\text { and Abbey }\end{array}$} \\
\hline vs. Challenger & 0.0001 & 0.007 & --- & 0.04 & 0.04 \\
\hline SF vs. TF & 0.0001 & 0.006 & --- & 0.02 & 0.01 \\
\hline SF vs. FF & NS & NS & --- & NS & NS \\
\hline SF vs. HF & NS & NS & --- & NS & NS \\
\hline TF vs. FF & 0.0001 & 0.03 & --- & 0.004 & 0.004 \\
\hline TF vs. HF & 0.0001 & 0.01 & --- & 0.05 & 0.03 \\
\hline FF vs. HF & NS & NS & --- & NS & NS \\
\hline
\end{tabular}

${ }^{\mathrm{z}} \mathrm{KB}=$ Kentucky bluegrass, $\mathrm{TF}=$ tall fescue, $\mathrm{HF}=$ hard fescue, $\mathrm{FF}=$ fine fescue, $\mathrm{SF}=$ sheep fescue.

${ }^{y} \mathrm{WUE}=$ water-use efficiency.

${ }^{x}$ The contrast was not performed on $\psi$ due to significant cultivar $x$ experiment interactions.

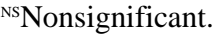

Table 7. Pearson correlation coefficient $(r)$ of electrolyte leakage (EL), relative water content (RWC), leaf water potential $(\psi)$, canopy temperature $\left(T_{c}\right)$, and canopy-air temperature difference $(\Delta T)$ with color score and water-use efficiency (WUE) for combined analysis of Expts. II and III.

\begin{tabular}{lccccc}
\hline \hline & \multicolumn{2}{c}{ Color score } & & \multicolumn{2}{c}{ WUE } \\
\cline { 2 - 3 } \cline { 5 - 6 } Variable & $r$ & $P$ & & $r$ & $P$ \\
\hline EL & -0.87 & 0.0001 & & -0.86 & 0.0001 \\
$\mathrm{RWC}$ & 0.62 & 0.003 & & 0.66 & 0.002 \\
$\Psi$ & -0.14 & $\mathrm{NS}$ & & -0.11 & NS \\
$\mathrm{T}_{\mathrm{c}}$ & -0.69 & 0.0007 & & -0.66 & 0.002 \\
$\Delta \mathrm{T}$ & -0.73 & 0.0003 & & -0.70 & 0.0006 \\
\hline
\end{tabular}

NSNonsignificant.

Physiological attributes. Cultivar effects of the combined analysis were statistically significant for RWC $(P=0.04)$ and EL $(P=$ 0.0001 ) but not significant for $\psi, \mathrm{T}_{c}$, and $\Delta \mathrm{T}$. Group contrasts for the combined analysis (Table 6) showed that RWC, EL, $\mathrm{T}_{c}$, and $\Delta \mathrm{T}$ can differentiate the water-use efficient group from the inefficient group and also cultivars between and within species; $\psi$ failed to differentiate the water-use efficient group from the inefficient group.

The correlations between $\psi, \mathrm{RWC}, \mathrm{T}_{\mathrm{c}}, \Delta \mathrm{T}$, and EL with color score and WUE for 10 cultivars are shown in Table 7. EL, $\mathrm{T}_{c}$, and $\Delta \mathrm{T}$ were significantly and negatively correlated with the color score and WUE, whereas RWC had a significant positive correlation with color score and WUE; $\psi$ was not significantly correlated with color score and WUE.

Based on their ability to separate cultivars and correlations with color score and WUE, EL and RWC are promising screening techniques. Furthermore, these two techniques are fairly easy and require simple equipment. $\mathrm{T}_{\mathrm{c}}$ and $\Delta \mathrm{T}$ can separate cultivar differences to some extent but not as well as EL and RWC. Ranking the cultivar effects using $\mathrm{T}$ and $\Delta \mathrm{T}$ correlates well with color score and WUE. Kneebone and Pepper (1979) found that, at equivalent soil moisture, differentials in transpiration levels could be distinguished between turfgrass species by using a hand-held infrared thermometer. Measuring temperature is nondestructive, easy, and large numbers of readings may be taken rapidly. The $\psi$ seems to be a poor selection criterion because it did not detect cultivar differences, required expensive equipment, and was time consuming.

Interrelationships between CET and physiological attributes are shown in a biplot display of $\mathrm{t}_{\mathrm{i}}, \Delta \mathrm{T}, \mathrm{EL}$, and color score (Fig. 4). Parameters that are either not significantly correlated with color score and WUE or have poor separation for cultivars were not included in the biplot to improve clarity. $\mathrm{T}_{c}$ and WUE were not included in the biplot because they were dependent with either $\Delta \mathrm{T}$ or color score. The first dimension, which explains $\approx 90 \%$ of the variation, can be considered as the overall WUE index, since it is a weighted difference between $\mathrm{ET}_{\max }, \mathrm{RWC}$, color score, $\Delta \mathrm{T}$, and EL. Thus, the first dimension effectively separated the cultivars into groups with relatively high and low WUE. The angles and the directions between the variable vectors illustrate the strength and the negative-positive correlations between variables. The second dimension, which explained $\approx 10 \%$ of the total variation, mainly accounted for differences in $t_{i}$. The cultivars with relatively high WUE were 'Abbey', 'Aurora', 'Bristol', 'FRT-30149', 'Meck', 'MX86', and 'Wabash'. 'Arid' and 'Bonanza' tall fescue and 'Challenger' Kentucky bluegrass had relatively low WUE.

In conclusion, there was a significant interaction between cultivar and day for $\mathrm{ET}_{\text {cum }}$. Two of the $\mathrm{ET}_{\text {cum }}$ attributes, $\mathrm{t}_{\mathrm{i}}$ and $\mathrm{ET} \mathrm{Tax}_{\text {, }}$, appeared to reflect efficient water-use attributes in the turfgrass cultivars. Based on $\mathrm{t}_{\mathrm{i}}, \mathrm{ET}_{\text {max }}$, and color score, 'Wabash', 'Bristol', 'Aurora', 'Shademaster', and 'FRT-30149' were identified as cultivars with relatively high WUE, whereas 'Apache', 'Bonanza', 'Arid', 'Citation', and 'Omega' were identified as cultivars with relatively low WUE. The ranking of the turfgrass cultivars in a previous greenhouse study generally correlates well with the present field study.

$\mathrm{EL}, \mathrm{RWC}$, and $\Delta \mathrm{T}$ are promising screening techniques for drought resistance in turfgrass. EL, $\mathrm{T}$, and $\Delta \mathrm{T}$ were significantly and negatively correlated with the color score and WUE, whereas RWC had a significant positive correlation with color score and WUE; $\psi$ was not significantly correlated with color score and WUE. Based on biplot display of six screening techniques, 'Abbey', 'Aurora', 'Bristol', 'FRT-30149', 'Meck', 'MX86', and 'Wabash' were identified as cultivars with relatively high WUE.

\section{Literature Cited}

Barrs, H.D. 1968. Determination of water deficits in plant tissues, p. 235-368. In: T.T. Kozlowski (ed.). Water deficits and plant growth. vol. 1. Development, control, and measurement. Academic Press, New York.

Beard, J.B. 1985. An assessment of water use by turfgrasses, p. 47-60. In: V.A. Gibeault and S.T. Cockerham (eds.). Turfgrass water conservation. Univ. Calif. Div. Agr. Natural Resources Publ. 21405.

Beard, J.B. 1990. Turfgrass selection and management to achieve maximum water conservation. Proc. Conserv 90, Conserv 90 Managing Partners. 


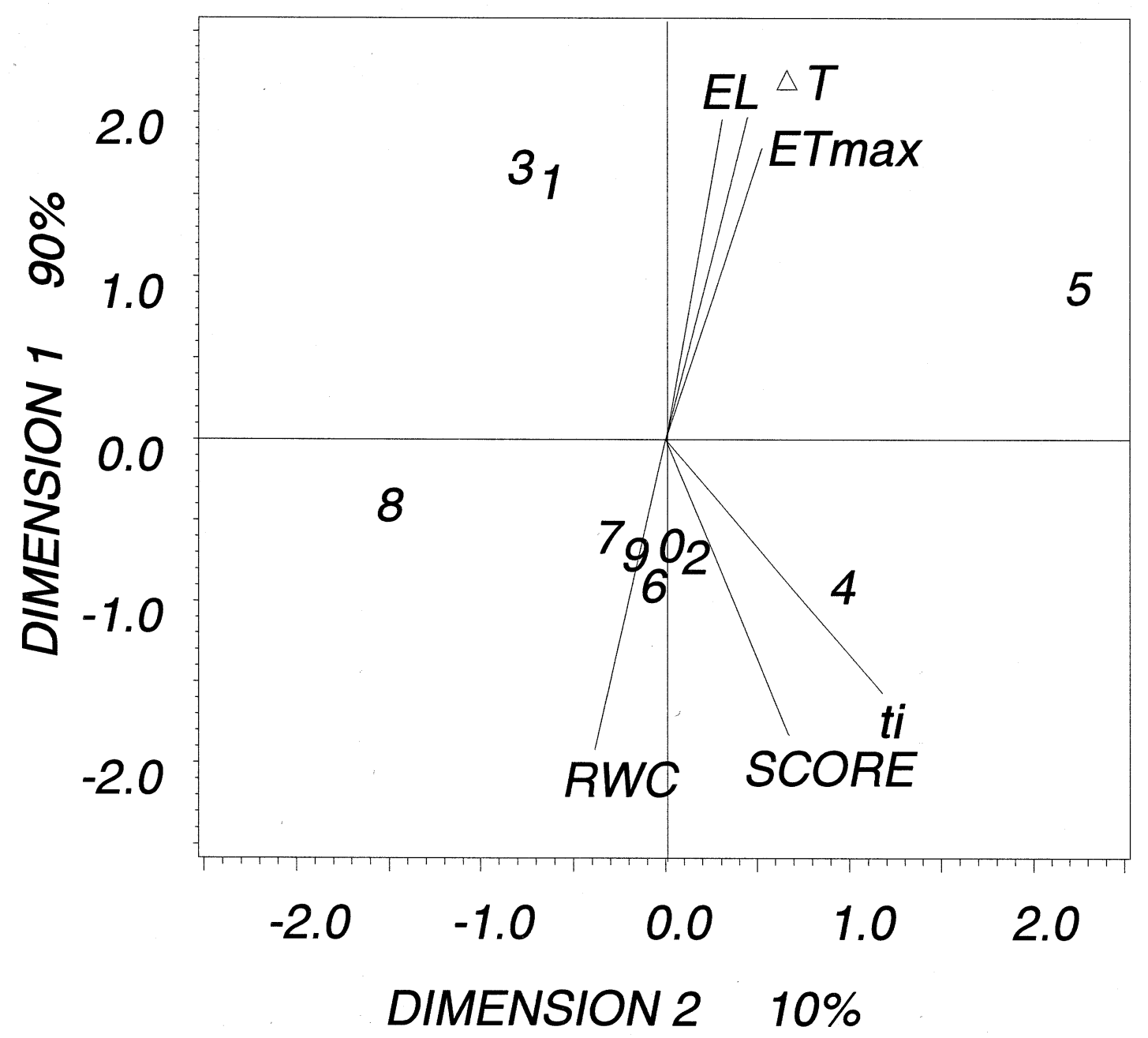

\section{Cultivars: $0=$ Abbey $1=$ Arid $2=$ Aurora $3=$ Bonanza $4=$ Bristol 5=Challenger 6=FRT30149 7=Meck 8=MX86 9=Wabash}

Fig. 4. Biplot display of drought resistance selection criteria and turfgrass cultivars. The first dimension, which accounts for $\approx 90 \%$ of the variation, can be considered as the overall water use efficiency index, since it is a weighted difference between maximum evapotranspiration (ET ${ }_{\max }$ ), relative water content (RWC), color score, canopy-air temperature difference $(\Delta \mathrm{T})$, and electrolyte leakage $(\mathrm{EL})$. The second dimension, which explained $\approx 10 \%$ of the total variation, mainly accounted for the differences in mean inflection time $\left(\mathrm{t}_{\mathrm{i}}\right)$.

Blum, A. 1988. CRC plant breeding for stress environments. CRC Press, Boca Raton, Fla. Blum, A., J. Mayer, and G. Gozlan. 1982. Infrared thermal sensing of plant canopies as a screening techniques for dehydration avoidance in wheat. Field Crops Res. 5:137146.

Bowman, D.C. and L. Macaulay. 1991. Comparative evapotranspiration rates of tall fescue cultivars. HortScience 26:122-123.

Brown, R.W. and D.L. Bartos. 1982. A calibration model for screen-caged Peltier thermocouple psychrometers. U.S. Dept. of Agr. For. Survey Res. Paper INT-293. Intermt. For. and Range Expt. Sta., Ogden, Utah.

Fernandez, G.C.J. 1991. Repeated measure analysis of line-source sprinkler experiments. HortScience 26:339-342

Fernandez, G.C.J. and B. Love. 1993. Comparison of turfgrass cumulative evapotranspiration curves. HortScience 28:732-734.

Fischer, R.A. and M. Sanchez. 1979. Drought resistance in spring wheat cultivars. II. Effects on plant water relations. Austral. J. Agr. Res. 30:801-814.

Gabriel, K.R. 1971. The biplot graphical display of matrices with application to principal component analysis. Biometrika 58:453-467

Hanson, A.D. and C.E. Nelson. 1980. Water: Adaptation of crops to drought-prone environments, p. 78-147. In: P.S. Carlson (ed.). The biology of crop productivity.

Hoagland, D.R. and D.I. Arnon. 1950. The water culture method for growing plants without soil. Calif. Agr. Expt. Sta. Circ. 347.

Kneebone, W.R., D.M. Kopec, and C.F. Mancino. 1992. Water requirements and irrigation. In:
D.V. Waddington, R.N. Carrow, and R.C. Shearman (eds.). Turfgrass. Agron. no. 32

Kneebone, W.R. and I.L. Pepper. 1979. Water requirements for urban lawns. Arizona Project Completion Rpt. OWRT Project no. B-035-WYO. Part 1.

Levitt, J. 1980. Responses of plants to environmental stresses. vol. 1. Chilling, freezing, and high temperature stress. Academic Press, New York.

Matin, M.A., J.H. Brown, and H. Ferguson. 1989. Leaf water potential, relative water content, and diffuse resistance as screening techniques for drought resistance in barley. Agron. J. 81:100-105.

Salaiz, T.A., R.C. Shearman, T.P. Riordan, and E.J. Kinbacher. 1991. Creeping bentgrass cultivars water use and rooting responses. Crop Sci. 31:1331-1334.

Sojka, R.E., L.H. Stolzy, and R.A. Fischer. 1981. Seasonal drought response of selected wheat cultivars. Agron. J. 73:838-845.

Sullivan, C.Y. 1972. Mechanisms of heat and drought resistance in grain sorghum and methods of measurements. In: N.G.P. Rao and L.R. House (eds.). Sorghum in the seventies. Oxford \& IBH Publishing Co., New Delhi, India.

Sullivan, C.Y. and W.M. Ross. 1979. Selecting for drought and heat resistance in grain sorghum. p. 263-281. In: H. Mussell and R.C. Staples (ed.). Stress physiology in crop plants. Wiley, New York.

Tipton, J.L. 1984. Evaluation of three growth curve models for germination analysis. J. Amer. Soc. Hort. Sci. 109:451-454

Tukey, J.W. 1949. One degree of freedom for non-additivity. Biometrics 5:232-242.

Van Bavel, C.H.M., R. Lascano, and D.R. Wilson. 1978. Water relations of fritted clay. Soil Sci. Soc. Amer. J. 42:657-659. 